Article

\title{
Nickel Catalyzed Conversion of Cyclohexanol into Cyclohexylamine in Water and Low Boiling Point Solvents
}

\author{
Yunfei $\mathrm{Qi}^{1,2}{ }^{1}$, Haiyun $\mathrm{Yu}^{1, *}$, Quan Cao ${ }^{2}$, Bo Dong ${ }^{2}$, Xindong $\mathrm{Mu}^{2}$ and Aiqing Mao ${ }^{1}$ \\ 1 Key Laboratory of materials Science and Processing of Anhui Province, School of Materials Science and \\ Engineering, Anhui University of Technology, Ma'anshan 243002, Anhui, China; \\ yunfei_q0218@foxmail.com (Y.Q.); maoaiqin@ahut.edu.cn (A.M.) \\ 2 Key Laboratory of Bio-Based Materials, Qingdao Institute of Bioenergy and Bioprocess Technology, \\ Chinese Academy of Sciences, Qingdao 266101, China; caoquan@qibebt.ac.cn (Q.C.); \\ xiguxilan@gmail.com (B.D.); muxd@qibebt.ac.cn (X.M.) \\ * Correspondence: yuhyahut@foxmail.com; Tel.: +86-532-8066-2725; Fax: +86-532-8066-2724 \\ Academic Editor: Keith Hohn \\ Received: 18 January 2016; Accepted: 31 March 2016; Published: 26 April 2016
}

\begin{abstract}
Nickel is found to demonstrate high performance in the amination of cyclohexanol into cyclohexylamine in water and two solvents with low boiling points: tetrahydrofuran and cyclohexane. Three catalysts, Raney $\mathrm{Ni}, \mathrm{Ni} / \mathrm{Al}_{2} \mathrm{O}_{3}$ and $\mathrm{Ni} / \mathrm{C}$, were investigated and it is found that the base, hydrogen, the solvents and the support will affect the activity of the catalyst. In water, all the three catalysts achieved over $85 \%$ conversion and $90 \%$ cyclohexylamine selectivity in the presence of base and hydrogen at a high temperature. In tetrahydrofuran and cyclohexane, $\mathrm{Ni} / \mathrm{Al}_{2} \mathrm{O}_{3}$ exhibits better activity than $\mathrm{Ni} / \mathrm{C}$ under optimal conditions. $\mathrm{Ni} / \mathrm{C}$ was stable during recycling in aqueous ammonia, while $\mathrm{Ni} / \mathrm{Al}_{2} \mathrm{O}_{3}$ was not due to the formation of $\mathrm{AlO}(\mathrm{OH})$.
\end{abstract}

Keywords: nickel; cyclohexanol; cyclohexylamine; base; hydrogen

\section{Introduction}

Amines find wide application in polymers, dyes, surfactants, pharmaceuticals, and biologically active compounds [1-10]. The amine is usually produced through direct amination of alcohol with ammonia. As shown in Scheme 1, this process includes dehydrogenation of alcohol to carbonyl compounds, amination of carbonyl compounds to imine, and hydrogenation of imine [11] to amine to produce primary, secondary and tertiary amine. Among the three, primary amine is the most useful intermediate for synthesizing value-added derivatives [12]. However, it is subject to subsequent amination due to its higher activity than ammonia and thus produces secondary and tertiary amine [5]. By now, great efforts have been made to find and develop a catalyst system to convert alcohol into primary amine. Homogeneous catalysts, such as Ru complexes, demonstrate high performance in converting secondary alcohol into primary amine [1-3]. However, these catalysts are either costly or difficult in recycling. Recently, work by Shimizu et al. showed that heterogeneous supported nickel catalysts, especially $\mathrm{Ni} / \mathrm{Al}_{2} \mathrm{O}_{3}$, is a choice catalyst for amination of alcohol into a primary amine with more than $80 \%$ amine yield [13]. In their work, the toxic $o$-xylene ais high in boiling point $\left(144{ }^{\circ} \mathrm{C}\right)$ and consumes more energy during the separation. Moreover, the solubility of alcohol in $o$-xylene is limited due to the presence of hydroxyl group. Therefore, much work needs to be done to find and use non-toxic or low boiling solvents. 


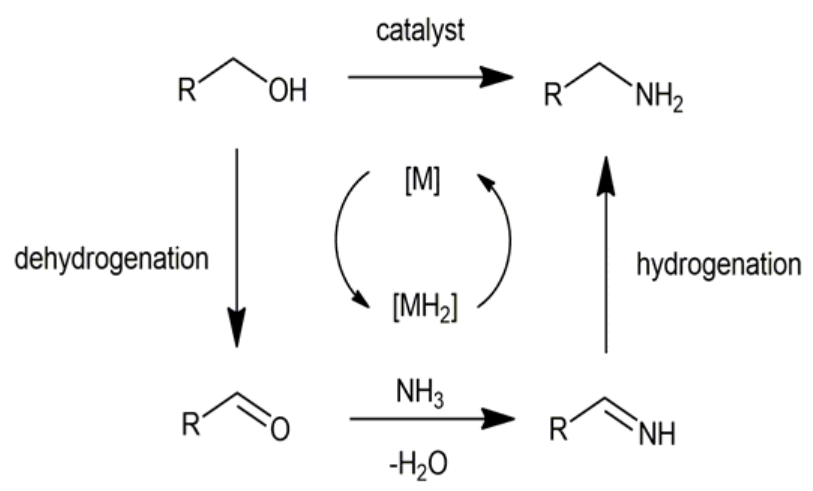

Scheme 1. The mechanism for amination of alcohol.

In the present work, aqueous ammonia, tetrahydrofuran, and cyclohexane are employed as solvents on the amination of cyclohexanol into cyclohexylamine using Raney $\mathrm{Ni}, \mathrm{Ni} / \gamma-\mathrm{Al}_{2} \mathrm{O}_{3}$ and $\mathrm{Ni} / \mathrm{C}$ catalysts. Water is non-toxic and the other two solvents are low in boiling points.

\section{Results and Discussion}

\subsection{Raney Ni in Aqueous Ammonia}

The reactivity of cyclohexanol was first investigated in aqueous ammonia using Raney Ni catalyst, which has already been commercialized. It is theoretically difficult to convert cyclohexanol in aqueous ammonia, because it is reversible to produce imine through dehydration of carbonyl with $\mathrm{NH}_{3}$ [14] The existence of a large amount of water will do no good to the formation of imine. It can be seen from Table 1 that Raney Ni itself only achieved 44\% cyclohexanol conversion (Entry 1). After $\mathrm{NaOH}$ is added, it dramatically enhanced its catalytic activity and obtained more than $90 \%$ conversion, indicating the base is helpful for the reaction. This result is consistent with the literature that base can promote the amination of alcohol [15]. However, it can be seen from Table 1 Entries 2 to 6 that it will not affect the conversion even further increasing the $\mathrm{NaOH}$ amount after $0.3 \mathrm{~g} \mathrm{NaOH}$ is added. When the Raney $\mathrm{Ni}$ catalysts in Table 1, Entry 6, were recycled for the second time, only 57\% cyclohexanol conversion was achieved (Entry 7). Raney Ni before and after the reaction (Entry 6) was observed by X-ray diffraction (XRD) with the results displayed in Figure 1. According to Scherrer equation in Equation (1), Raney Ni before and after reaction was estimated to be $7 \mathrm{~nm}$ and $15 \mathrm{~nm}$ in crystallite size. The reason why the catalyst deactivates may be ascribed to the growth of the crystallite size.

$$
D=K \lambda / B \cos \theta
$$

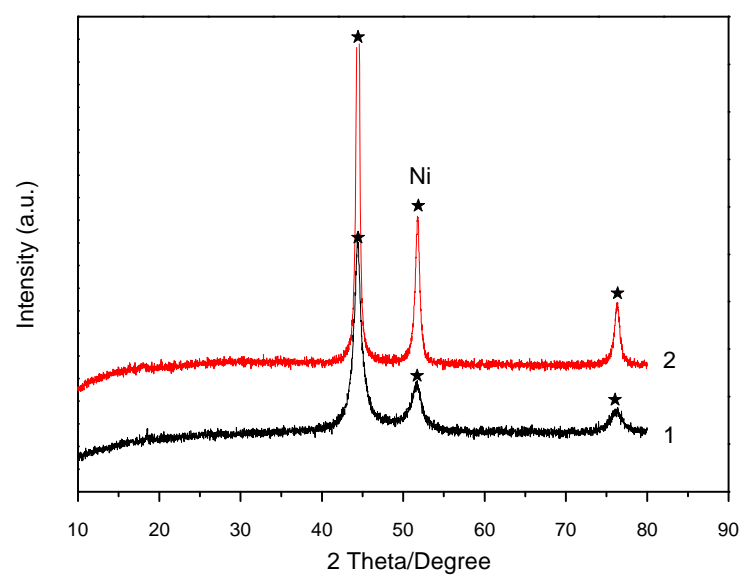

Figure 1. X-ray diffraction (XRD) patterns of (1) fresh Raney Ni; (2) Raney Ni used in Table 1, Entry 6. 
Table 1. Conversion of cyclohexanol into cyclohexylamine over Raney Ni in aqueous ammonia with different amount of $\mathrm{NaOH}^{\mathrm{a}}$.

\begin{tabular}{cccc}
\hline Entry & $\mathbf{N a O H} / \mathbf{g}$ & Conversion/\% & Yield/\% \\
\hline 1 & 0 & 44 & 41 \\
2 & 0.3 & 93 & 79 \\
3 & 0.4 & 95 & 78 \\
4 & 0.5 & 95 & 84 \\
5 & 0.6 & 96 & 90 \\
6 & 0.7 & 96 & 89 \\
$7^{\mathrm{b}}$ & 0.7 & 57 & 52 \\
\hline
\end{tabular}

a Reaction conditions: Raney Ni 6 g; aqueous ammonia 28 g; cyclohexanol 1 g; $160{ }^{\circ} \mathrm{C} ; 17 \mathrm{~h} ;{ }^{\mathrm{b}}$ Raney Ni (Entry 6) was recycled for the second time.

Table 2 shows that both the conversion and yield increase as the reaction time extends, while the selectivity decreases over time. Eight hours is enough for the reaction to achieve $94 \%$ conversion. It will not significantly improve the conversion even if the reaction time is prolonged.

Table 2. Conversion of cyclohexanol into cyclohexylamine over Raney Ni with different time.

\begin{tabular}{ccccc}
\hline Entry & Time/h & Conversion/\% & Yield/\% & Selectivity/\% \\
\hline 1 & 4 & 71 & 68 & 95 \\
2 & 6 & 83 & 76 & 91 \\
3 & 8 & 94 & 81 & 86 \\
4 & 12 & 95 & 82 & 86 \\
5 & 17 & 96 & 82 & 85 \\
6 & 24 & 98 & 83 & 84 \\
7 & 30 & 98 & 83 & 84 \\
\hline
\end{tabular}

Reaction conditions: Raney Ni 6 g; aqueous ammonia 28 g; cyclohexanol 1 g; $160^{\circ} \mathrm{C} ; 0.5 \mathrm{~g} \mathrm{NaOH}$.

The effect of cyclohexanol concentration on the reaction was displayed in Table 3, indicating that higher concentration leads to lower selectivity. Because theoretically the cyclohexylamine produced can further react with cyclohexanol to produce dicyclohexyl amine and even tricyclic hexylamine [6]. However, only dicyclohexyl amine was produced while tricyclic hexylamine was not detected in this work. Further investigation demonstrated that dicyclohexyl amine could not be converted into cyclohexylamine under the reaction conditions in Table 3.

Table 3. Conversion of cyclohexanol into cyclohexylamine over Raney Ni with different amount of cyclohexanol.

\begin{tabular}{ccccc}
\hline Entry & Alcohol/g & Conversion/\% & Yield/\% & Selectivity $/ \%$ \\
\hline 1 & 1 & 96 & 88 & 93 \\
2 & 1.5 & 93 & 86 & 92 \\
3 & 2 & 89 & 76 & 85 \\
4 & 2.5 & 93 & 72 & 77 \\
\hline
\end{tabular}

\section{2. $\mathrm{Ni} / \mathrm{Al}_{2} \mathrm{O}_{3}$ and $\mathrm{Ni} / \mathrm{C}$ Systems}

Supported catalyst is generally more popular due to its less use of active metal. Moreover, the support is found to exert great influence to the activity of the catalyst $[13,16,17]$. Two supports $\mathrm{Al}_{2} \mathrm{O}_{3}$ and active carbon were investigated in aqueous ammonia with the results shown in Table 4 . From Entries 1 to 3, as the temperature was raised form $160{ }^{\circ} \mathrm{C}$ to $200{ }^{\circ} \mathrm{C}$, it resulted in an increase of conversion from $51 \%$ to $71 \%$. The conversion increases with the reaction time prolonging and then 
reaches a plateau for both $\mathrm{Ni} / \mathrm{Al}_{2} \mathrm{O}_{3}$ and $\mathrm{Ni} / \mathrm{C}$ catalysts (Entries 4 to 6 and 10 to 12). Through the comparison between Entry 3 and 7, Entry 8 and 9, the conversion increased from $48 \%$ to $71 \%$ and $37 \%$ to $87 \%$, respectively, indicating that $\mathrm{NaOH}$ can improve the catalytic activity of both $\mathrm{Ni} / \mathrm{Al}_{2} \mathrm{O}_{3}$ and $\mathrm{Ni} / \mathrm{C}$. In the amination reaction, hydrogen also participated in the dehydrogenation and the hydrogenation process. The effect of hydrogen is also tested, and as shown in Table 4 Entries 3, 6, 9 and 10 for $\mathrm{Ni} / \mathrm{Al}_{2} \mathrm{O}_{3}$ and $\mathrm{Ni} / \mathrm{C}$, the conversion increases from $71 \%$ to $87 \%$ and $87 \%$ to $92 \%$, respectively, suggesting that hydrogen has positive, though slight effect on the reaction for both $\mathrm{Ni} / \mathrm{Al}_{2} \mathrm{O}_{3}$ and $\mathrm{Ni} / \mathrm{C}$. At the same temperature of $160^{\circ} \mathrm{C}$ (Entries 1 and 9), $\mathrm{Ni} / \mathrm{C}$ exhibits better activity than $\mathrm{Ni} / \mathrm{Al}_{2} \mathrm{O}_{3}$, indicating the support may affect the activity of nickel [13]. From Figure 2, $\mathrm{Ni}$ in the fresh $\mathrm{Ni} / \mathrm{Al}_{2} \mathrm{O}_{3}$ and $\mathrm{Ni} / \mathrm{C}$ catalysts were $14 \mathrm{~nm}$ and $6 \mathrm{~nm}$, respectively, in crystallite size based on the Scherrer equation. $\mathrm{C}\left(1211 \mathrm{~m}^{2} / \mathrm{g}\right)$ is larger than $\mathrm{Al}_{2} \mathrm{O}_{3}\left(163 \mathrm{~m}^{2} / \mathrm{g}\right)$ in surface area. Therefore, Ni on $\mathrm{C}$ gives higher $\mathrm{Ni}$ surface areas than that of $\mathrm{Ni}$ on $\mathrm{Al}_{2} \mathrm{O}_{3}$. The difference in nickel surface area could explain the better activity of $\mathrm{Ni} / \mathrm{C}$ catalyst.

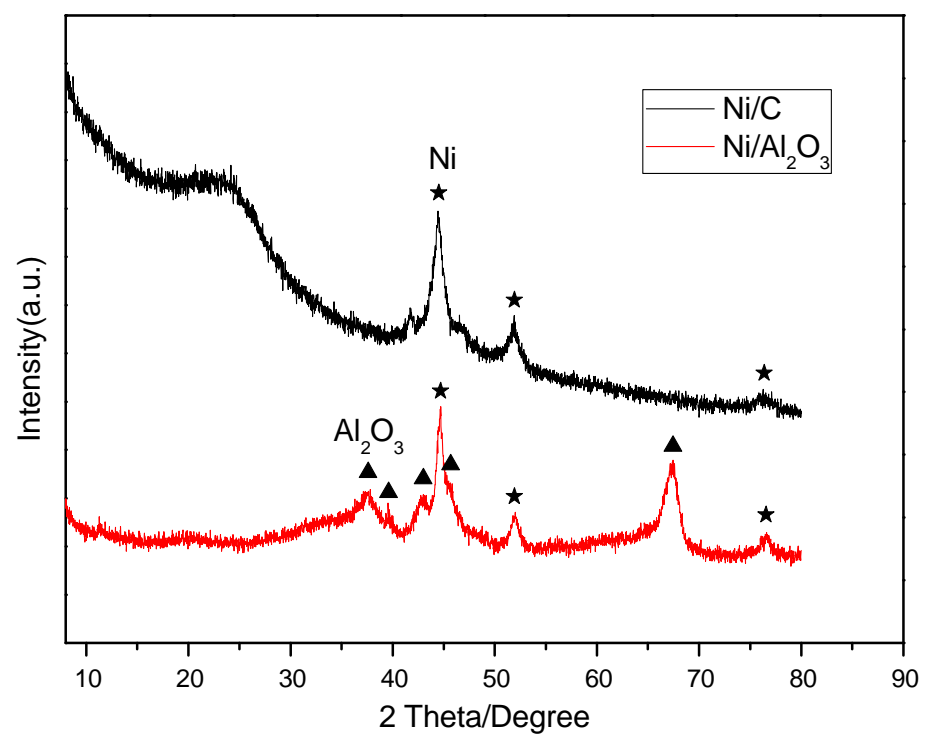

Figure 2. XRD patterns of fresh $\mathrm{Ni} / \mathrm{Al}_{2} \mathrm{O}_{3}$ and $\mathrm{Ni} / \mathrm{C}$.

Table 4. Catalytic activity of $\mathrm{Ni} / \mathrm{Al}_{2} \mathrm{O}_{3}$ and $\mathrm{Ni} / \mathrm{C}$ in aqueous ammonia.

\begin{tabular}{cccccccc}
\hline Entry & Catalyst & $\mathbf{T} /{ }^{\circ} \mathbf{C}$ & $\mathbf{t} / \mathbf{h}$ & $\mathbf{H}_{\mathbf{2}} / \mathbf{M P a}$ & $\mathbf{N a O H} / \mathbf{g}$ & Conversion/\% & Yield/\% \\
\hline 1 & $\mathrm{Ni} / \mathrm{Al}_{2} \mathrm{O}_{3}$ & 160 & 17 & 0 & 0.3 & 51 & 42 \\
2 & $\mathrm{Ni} / \mathrm{Al}_{2} \mathrm{O}_{3}$ & 180 & 17 & 0 & 0.3 & 54 & 49 \\
3 & $\mathrm{Ni} / \mathrm{Al}_{2} \mathrm{O}_{3}$ & 200 & 17 & 0 & 0.3 & 71 & 65 \\
4 & $\mathrm{Ni} / \mathrm{Al}_{2} \mathrm{O}_{3}$ & 200 & 8 & 1 & 0.3 & 63 & 54 \\
5 & $\mathrm{Ni} / \mathrm{Al}_{2} \mathrm{O}_{3}$ & 200 & 14 & 1 & 0.3 & 82 & 72 \\
6 & $\mathrm{Ni} / \mathrm{Al}_{2} \mathrm{O}_{3}$ & 200 & 17 & 1 & 0.3 & 87 & 79 \\
7 & $\mathrm{Ni} / \mathrm{Al}_{2} \mathrm{O}_{3}$ & 200 & 17 & 0 & 0 & 48 & 41 \\
8 & $\mathrm{Ni} / \mathrm{C}$ & 160 & 17 & 0 & 0 & 37 & 34 \\
9 & $\mathrm{Ni} / \mathrm{C}$ & 160 & 17 & 0 & 0.3 & 87 & 81 \\
10 & $\mathrm{Ni} / \mathrm{C}$ & 160 & 17 & 1 & 0.3 & 92 & 85 \\
11 & $\mathrm{Ni} / \mathrm{C}$ & 160 & 6 & 1 & 0.3 & 76 & 69 \\
12 & $\mathrm{Ni} / \mathrm{C}$ & 160 & 24 & 1 & 0.3 & 91 & 81 \\
13 & $\mathrm{Ni} / \mathrm{C}$ & 180 & 17 & 1 & 0.3 & 91 & 86 \\
\hline
\end{tabular}

Reaction conditions: cyclohexanol $1 \mathrm{~g}$, aqueous ammonia $28 \mathrm{~g}$, catalyst $1 \mathrm{~g}$ (Ni $10 \mathrm{wt} \%$ ). 


\subsection{Recycling of the Catalysts}

$\mathrm{Ni} / \mathrm{C}$ exhibits better activity than $\mathrm{Ni} / \mathrm{Al}_{2} \mathrm{O}_{3}$, thus its stability during the reaction is further investigated. The results, as shown in Figure 3, indicate that in the presence of $\mathrm{NaOH}$ and $\mathrm{H}_{2}$, $\mathrm{Ni} / \mathrm{C}$ could be reused six times without losing its activity and each cycle generated more than $80 \%$ cyclohexylamine yield. However, after being recycled two times, $\mathrm{Ni} / \mathrm{Al}_{2} \mathrm{O}_{3}$ (Table 4 Entry 6) became less active. It only achieved $61 \%$ conversion and $53 \%$ yield for the second run. The XRD characterization shown in Figures 4 and 5 demonstrated that $\mathrm{Ni} / \mathrm{C}$ retained its structure after being recycled, while $\mathrm{Al}_{2} \mathrm{O}_{3}$ reacted with water and produced $\mathrm{AlO}(\mathrm{OH})$. From Figures 4 and $5 \mathrm{Ni}$ in Ni/ $\mathrm{Al}_{2} \mathrm{O}_{3}$ and $\mathrm{Ni} / \mathrm{C}$ catalysts increased from $14 \mathrm{~nm}$ to $23 \mathrm{~nm}$ and $6 \mathrm{~nm}$ to $7 \mathrm{~nm}$ after being recycled, respectively in crystallite size according to the Scherrer equation. High Resolution Transmission Electron Microscopy (HRTEM) analysis of $\mathrm{Ni} / \mathrm{Al}_{2} \mathrm{O}_{3}$ catalysts before and after the reaction as shown in Figures 6 and 7 further proved that some of $\mathrm{Ni}$ were lost from the surface of $\mathrm{Al}_{2} \mathrm{O}_{3}$ because of the formation of $\mathrm{AlO}(\mathrm{OH})$. The Inductively Coupled Plasma optical emission spectrometry (ICP-OES) analysis demonstrated that $11 \% \mathrm{Ni}$ on $\mathrm{Ni} / \mathrm{Al}_{2} \mathrm{O}_{3}$ was lost. As to $\mathrm{Ni} / \mathrm{C}$ catalyst, HRTEM analysis (Figures 8 and 9) indicated that less $\mathrm{Ni}$ on $\mathrm{C}$ was lost than that on $\mathrm{Al}_{2} \mathrm{O}_{3}$, which is consistent with the fact that only $0.5 \% \mathrm{Ni}$ on $\mathrm{C}$ was lost by ICP-OES analysis. The substantial loss of metal and the growth of the crystallite size may be the reason for the deactivation of the $\mathrm{Ni} / \mathrm{Al}_{2} \mathrm{O}_{3}$ catalyst; while the small decrease of cyclohexylamine yield of $\mathrm{Ni} / \mathrm{C}$ catalyst after being recycled in Figure 3 may be ascribed to slight loss of Nickel and growth of crystallite size. It can thus be concluded from the above analysis that $\mathrm{Ni} / \mathrm{C}$ is a better choice than $\mathrm{Ni} / \mathrm{Al}_{2} \mathrm{O}_{3}$ during the amination of cyclohexanol in aqueous ammonia.

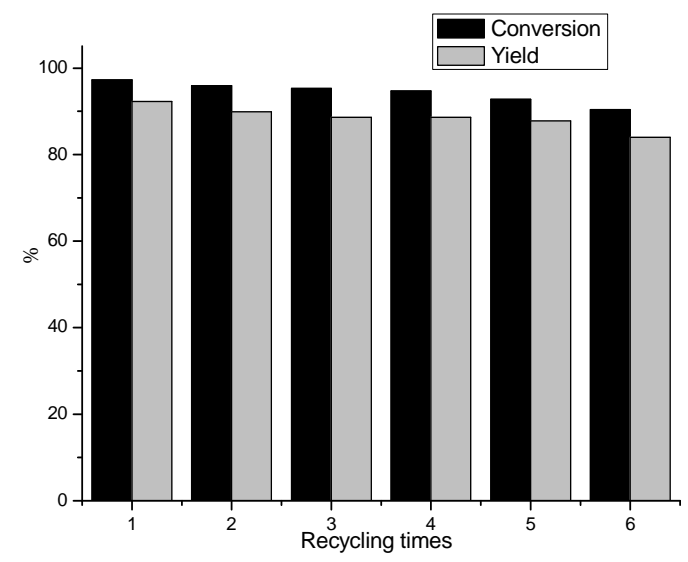

Figure 3. Recycling of $\mathrm{Ni} / \mathrm{C}$ catalyst. Conditions: $160{ }^{\circ} \mathrm{C}, 17 \mathrm{~h}, 1 \mathrm{MPa} \mathrm{H}_{2}, 1 \mathrm{~g}$ cyclohexanol, $1 \mathrm{~g} 10 \mathrm{wt} \%$ $\mathrm{Ni} / \mathrm{C}$ catalyst, $28 \mathrm{~g}(25 \mathrm{wt} \%)$ aqueous ammonia.

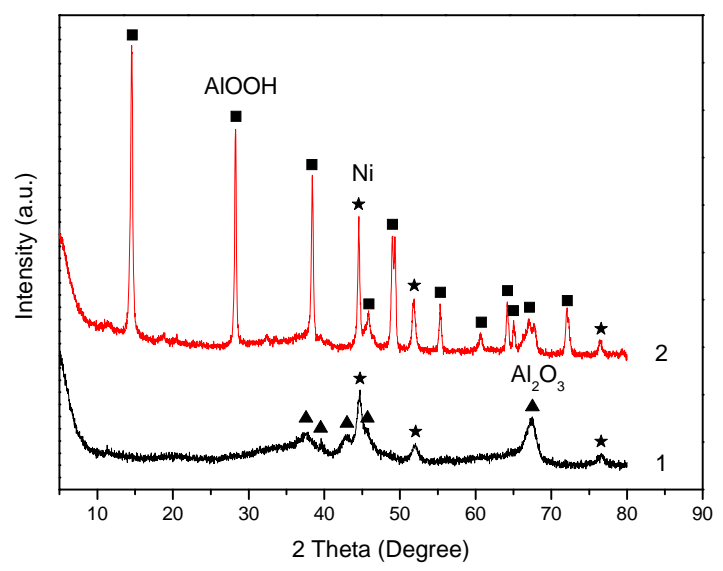

Figure 4. $\mathrm{XRD}$ patterns of $(\mathbf{1})$ fresh $\mathrm{Ni} / \mathrm{Al}_{2} \mathrm{O}_{3} ;(2) \mathrm{Ni} / \mathrm{Al}_{2} \mathrm{O}_{3}$ after the reaction. 


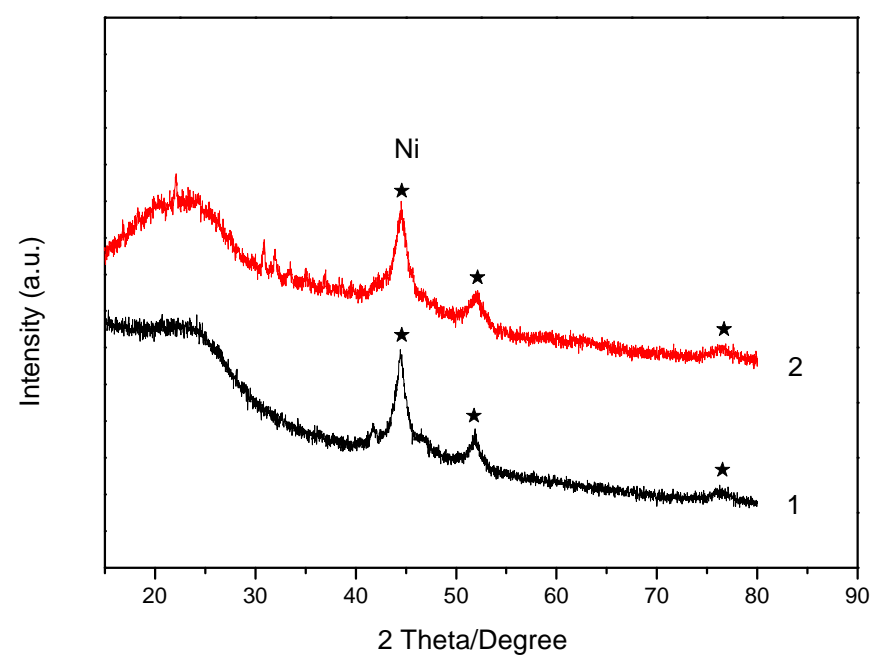

Figure 5. XRD patterns of (1) fresh $\mathrm{Ni} / \mathrm{C} ;(2) \mathrm{Ni} / \mathrm{C}$ after six times reaction.
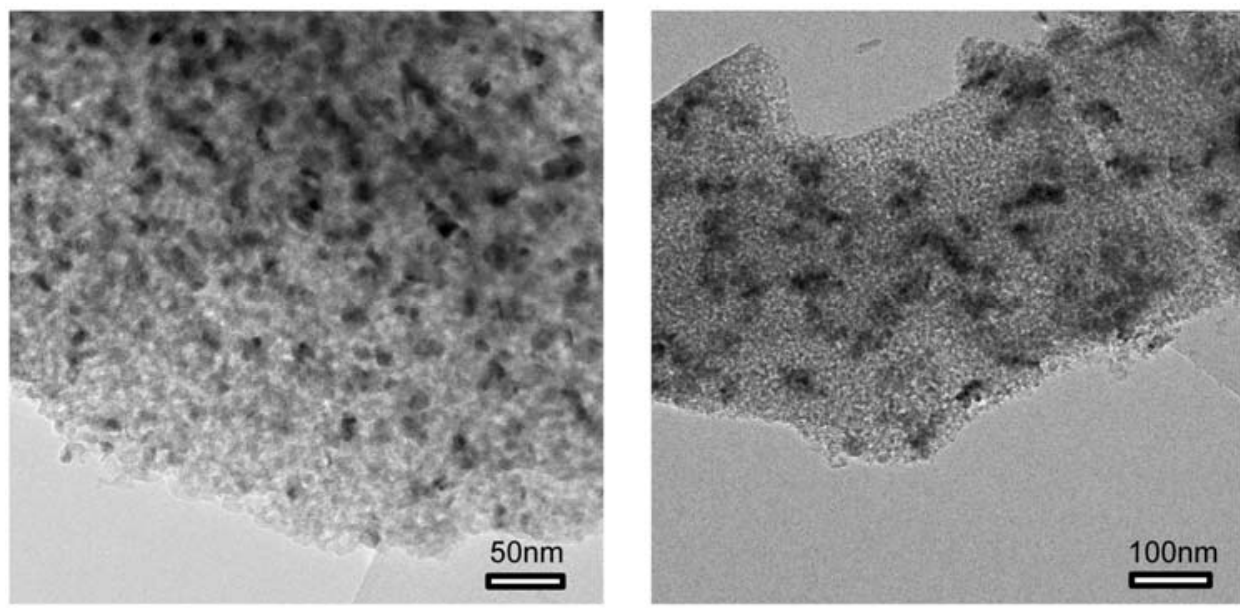

Figure 6. High Resolution Transmission Electron Microscopy (HRTEM) micrographs of the fresh $\mathrm{Ni} / \mathrm{Al}_{2} \mathrm{O}_{3}$ catalyst.

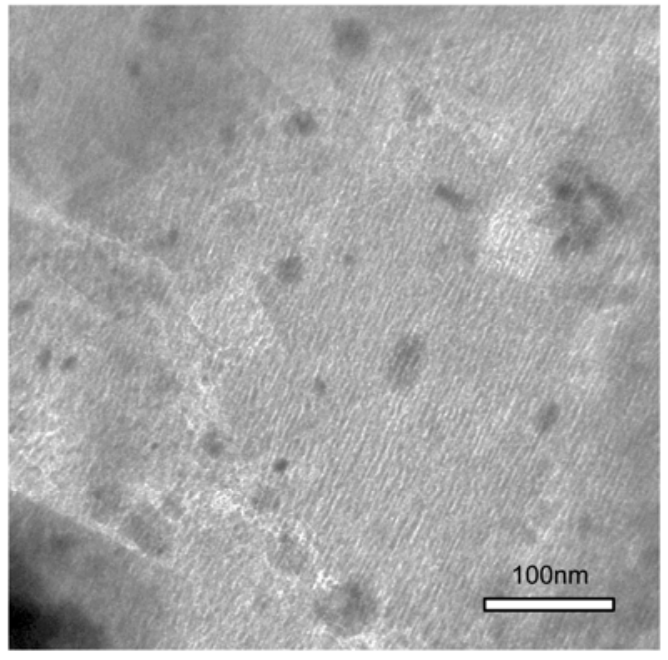

Figure 7. HRTEM micrograph of $\mathrm{Ni} / \mathrm{Al}_{2} \mathrm{O}_{3}$ catalyst after the reaction. 

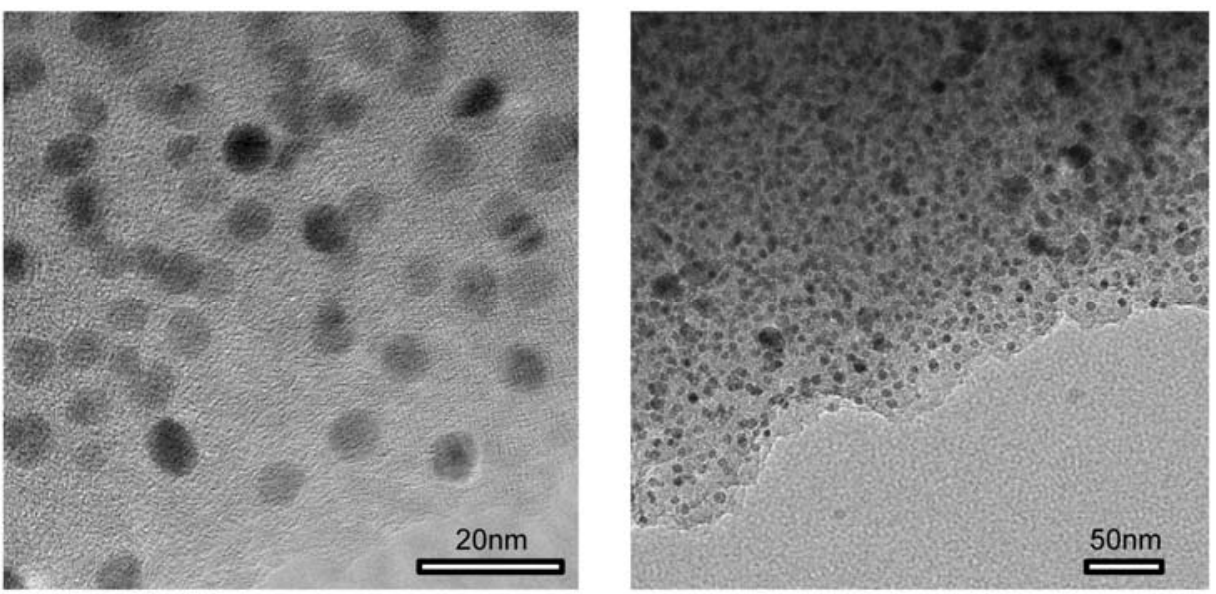

Figure 8. HRTEM micrographs of the fresh $\mathrm{Ni} / \mathrm{C}$ catalyst.
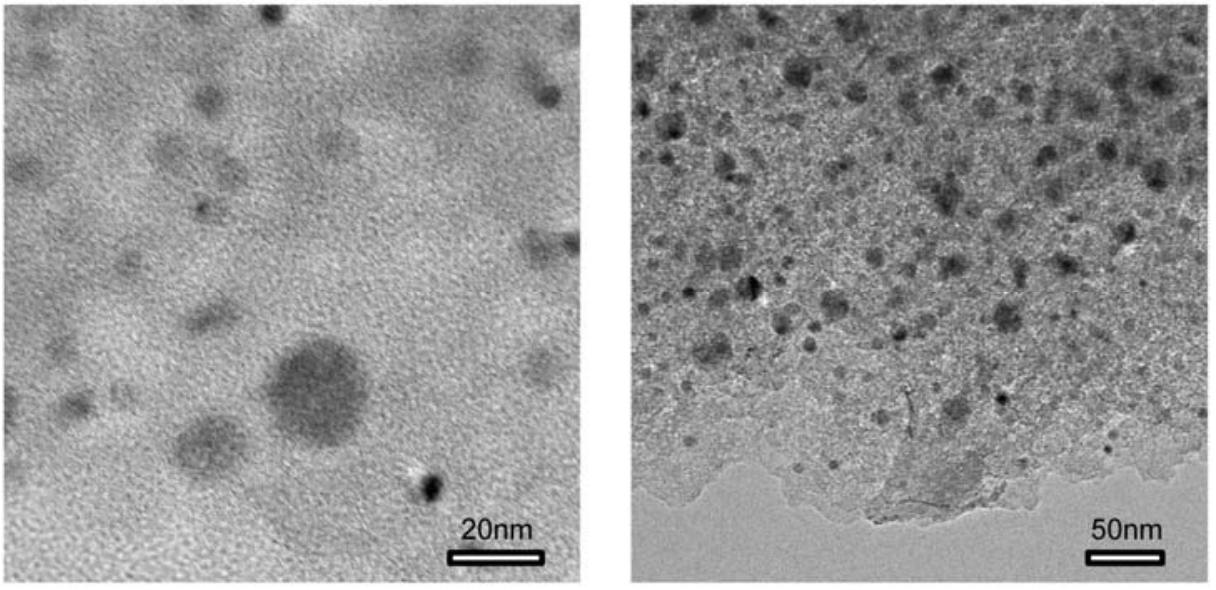

Figure 9. HRTEM micrographs of $\mathrm{Ni} / \mathrm{C}$ catalyst after six times reaction.

\subsection{Conversion in Low Boiling Point Solvents}

Although cyclohexanol could be efficiently converted in aqueous ammonia, the high boiling point of water may lead to high energy consumption during the separation process. Two solvents with low boiling points tetrahydrofuran (THF) and cyclohexane were therefore investigated. Amination of cyclohexanol in non-aqueous solvents goes on well with the absence of water. The polarity of the two solvents follows the order THF > cyclohexane, which influences the solubility of both the substrate and $\mathrm{NH}_{3}$ in them. It can be seen from Table 5 (Entries 1 to 4 ) that, in THF, NaOH plays a more important role than $\mathrm{H}_{2}$. The base can improve the conversion from $13 \%$ to $50 \%$ while hydrogen has no such dramatic effect. Raising the temperature from $160{ }^{\circ} \mathrm{C}$ to $180^{\circ} \mathrm{C}$ can lead to an increase of conversion from $50 \%$ to $85 \%$ (Entry 4 and 5). In the case of cyclohexane, the base is not soluble in it. The effect of the base in cyclohexane was thus not investigated. As can be seen from Table 5 Entries 6 and 7, hydrogen can improve the conversion from 31\% to 96\%. Comparing Entries 5 and 7, more cyclohexylamine yield is obtained in cyclohexane, indicating the solvent can affect the activity of $\mathrm{Ni} / \mathrm{Al}_{2} \mathrm{O}_{3}$, as the polarity of cyclohexane is smaller than that of THF. In cyclohexane, it is easier for cyclohexanol to adsorb on the surface of $\mathrm{Al}_{2} \mathrm{O}_{3}$ and facilitate the catalytic reaction. However, the major disadvantage of cyclohexane lies in its low ability to solubilize some polar alcohol. In that case, THF may be a better choice. 
Table 5. Conversion of cyclohexanol into cyclohexylamine over $\mathrm{Ni} / \mathrm{Al}_{2} \mathrm{O}_{3}$ in tetrahydrofuran (THF) and cyclohexane.

\begin{tabular}{ccccccc}
\hline Entry & Solvents & $\mathbf{T} /{ }^{\circ} \mathbf{C}$ & $\mathbf{H}_{\mathbf{2}} / \mathbf{M P a}$ & $\mathbf{N a O H} / \mathbf{g}$ & Conversion/\% & Yield/\% \\
\hline 1 & $\mathrm{THF}$ & 160 & 0 & 0 & 13 & 11 \\
2 & $\mathrm{THF}$ & 160 & 1 & 0 & 11 & 9 \\
3 & $\mathrm{THF}$ & 160 & 0 & 0.3 & 50 & 46 \\
4 & $\mathrm{THF}$ & 160 & 1 & 0.3 & 50 & 41 \\
5 & $\mathrm{THF}$ & 180 & 1 & 0.3 & 85 & 76 \\
6 & cyclohexane & 180 & 0 & 0 & 31 & 28 \\
7 & cyclohexane & 180 & 1 & 0 & 96 & 87 \\
\hline \multicolumn{2}{l}{ Reaction conditions: cyclohexanol $1 \mathrm{~g}, \mathrm{Ni}^{-\mathrm{Al}_{2} \mathrm{O}_{3}(\mathrm{Ni} 10 \mathrm{wt} \%)} 1 \mathrm{~g}$, solvent $25 \mathrm{~mL}, \mathrm{NH}_{3} 0.4 \mathrm{MPa}, 17 \mathrm{~h}}$.
\end{tabular}

Table 6 shows the activity of $\mathrm{Ni} / \mathrm{C}$ in cyclohexane and THF. Similar with $\mathrm{Ni} / \mathrm{Al}_{2} \mathrm{O}_{3}, \mathrm{NaOH}$ still plays a more important role than $\mathrm{H}_{2}$ (Entries 1, 2 and 3) in THF. At $180{ }^{\circ} \mathrm{C}$ in the presence of $\mathrm{H}_{2}$ and $\mathrm{NaOH}$, only $32 \%$ conversion was achieved for $\mathrm{Ni} / \mathrm{C}$ catalyst (Entry 4). While at $180^{\circ} \mathrm{C}$ in cyclohexane, $42 \%$ conversion was obtained (Entry 5). Compared with Table $5, \mathrm{Ni} / \mathrm{Al}_{2} \mathrm{O}_{3}$ is superior to $\mathrm{Ni} / \mathrm{C}$ both in THF and cyclohexane.

Table 6. Conversion of cyclohexanol into cyclohexylamine over Ni/C in THF and cyclohexane.

\begin{tabular}{ccccccc}
\hline Entry & Solvent & $\mathbf{T} /{ }^{\circ} \mathbf{C}$ & $\mathbf{H}_{\mathbf{2}} / \mathbf{M P a}$ & $\mathbf{N a O H} / \mathbf{g}$ & Conversion/\% & Yield/\% \\
\hline 1 & THF & 160 & 0 & 0 & 11 & 9 \\
2 & THF & 160 & 0 & 0.3 & 22 & 20 \\
3 & THF & 160 & 1 & 0 & 12 & 10 \\
4 & THF & 180 & 1 & 0.3 & 32 & 28 \\
5 & cyclohexane & 180 & 1 & 0.3 & 42 & 35 \\
\hline
\end{tabular}

Reaction conditions: cyclohexanol $1 \mathrm{~g}$, Ni/C (Ni $10 \mathrm{wt} \%) 1 \mathrm{~g}$, solvent $25 \mathrm{~mL}, \mathrm{NH}_{3} 0.4 \mathrm{MPa}, 17 \mathrm{~h}$.

\section{Experimental Section}

\subsection{Materials}

Cyclohexanol ( $\geqslant 99 \%)$, cyclohexylamine ( $\geqslant 99 \%)$, aqueous ammonia $(25 \%-28 \%), \mathrm{NaOH}(\geqslant 99 \%)$, cyclohexane $(\geqslant 99 \%)$ and tetrahydrofuran $(\geqslant 99 \%)$ were purchased from Sinopharm Chemical Reagent Co., Ltd. (Shanghai, China). Nickel nitrate hexahydrate ( $\geqslant 98 \%)$ was purchased from Tianjin Science and Technology Co., Ltd. (Tianjin, China). Active carbon was supplied by Cabot Co., Ltd. (Boston, MA, USA). $\gamma-\mathrm{Al}_{2} \mathrm{O}_{3}$ was purchased from ShanDong Aluminium Industry Co., Ltd. (Shandong, China). Raney Ni was obtained from Dalian General Chemical Industry Co., Ltd. (Dalian, China). And 1, 6-hexanediol (>99\%) was bought from Aladdin (Shanghai, China).

\subsection{Catalyst Preparation}

$\mathrm{Ni} / \mathrm{Al}_{2} \mathrm{O}_{3}$ and $\mathrm{Ni} / \mathrm{C}(\mathrm{Ni} 10 \mathrm{wt} \%)$ catalysts were prepared by impregnation. A mixture of $\gamma-\mathrm{Al}_{2} \mathrm{O}_{3}$ or $\mathrm{C}$ and an aqueous solution of $\mathrm{Ni}\left(\mathrm{NO}_{3}\right)_{2} \cdot 6 \mathrm{H}_{2} \mathrm{O}$ was evaporated at $40{ }^{\circ} \mathrm{C}$ under reduced pressure, then dried at $110{ }^{\circ} \mathrm{C}$ for $12 \mathrm{~h}$. The as-synthesized Ni/ $\mathrm{Al}_{2} \mathrm{O}_{3}$ and $\mathrm{Ni} / \mathrm{C}$ were reduced in a tubular furnace under a flow of $\mathrm{H}_{2}$ at $500{ }^{\circ} \mathrm{C}$ for $6 \mathrm{~h}$.

\subsection{Catalyst Characterization}

X-ray diffraction (XRD) measurements were carried out by a Bruker D8 Advanced X-ray diffractometer using $\mathrm{Cu} \mathrm{K}_{\alpha}$ radiation $(\lambda=1.5147 \AA$, Karlsruhe, Germany).

High Resolution Transmission Electron Microscopy (HRTEM) measurements were carried out using an emission Tecnai G2F20 electron microscope (FEI, Hillsboro, OR, USA). 
The Brunauer-Emmett-Teller (BET) surface area of $\mathrm{Al}_{2} \mathrm{O}_{3}$ and active carbon was measured using a micromeritics (ASAP-2020 M + C). Samples were pretreated at $180{ }^{\circ} \mathrm{C}$ for $3 \mathrm{~h}$ under vacuum. $\mathrm{N}_{2}$ adsorption/desorption isotherms were measured at $77 \mathrm{~K}$. The surface areas were determined from adsorption values using the Brunauer-Emmett-Teller (BET) surface method.

The loss of Ni was determined using a Thermo IRIS IntrepidIIXSP Inductively Coupled Plasma Emission Spectrometer (Labcompare, South San Francisco, CA, USA).

\subsection{Typical Procedures for the Reactions}

Aqueous ammonia, cyclohexanol, $\mathrm{NaOH}$ and Raney Ni were charged into an autoclave, which was sealed and then heated under magnetic stirring at a preset temperature.

Tetrahydrofuran (or cyclohexane) and cyclohexanol were poured into the autoclave. The catalyst $\mathrm{Ni} / \mathrm{Al}_{2} \mathrm{O}_{3}$ or $\mathrm{Ni} / \mathrm{C}$ was then charged into the autoclave immediately after reduction under the protection of $\mathrm{N}_{2}$. The autoclave purged three times with $\mathrm{H}_{2}$ was pressured to $0.4 \mathrm{MPa} \mathrm{NH}_{3}$ under stirring for $30 \mathrm{~min}$. After being pressured to $1 \mathrm{MPa} \mathrm{H}_{2}$, the autoclave was heated under stirring at a preset temperature.

\subsection{Analytical Methods}

Gas chromatography (GC) analysis was conducted using a Varian-450 gas chromatograph (Varian, Salt Lake City, UT, USA) with a flame ionization detector. The temperature of the column (DB-5, $30 \mathrm{~m} \times 0.32 \mathrm{~mm} \times 0.25 \mu \mathrm{m}$ ) was maintained at $60^{\circ} \mathrm{C}$ for $1 \mathrm{~min}$ and then raised to $280^{\circ} \mathrm{C}$ with a ramp rate of $16^{\circ} \mathrm{C} / \mathrm{min}$ for $1 \mathrm{~min}$. The flowing rate of nitrogen was $1 \mathrm{~mL} / \mathrm{min}$ with a split ratio of 30:1. The yield of cyclohexylamine and the conversion of cyclohexanol were calculated using 1, 6-hexanediol as an internal standard.

\section{Conclusions}

It was found in the amination of cyclohexanol into cyclohexylamine over $\mathrm{Ni}$ catalysts in aqueous ammonia, THF and cyclohexane that the base had positive effect on the activity of Raney $\mathrm{Ni}, \mathrm{Ni} / \mathrm{Al}_{2} \mathrm{O}_{3}$ and $\mathrm{Ni} / \mathrm{C}$ in aqueous ammonia and THF. Hydrogen could also improve the conversion of cyclohexanol. In aqueous ammonia, $\mathrm{Ni} / \mathrm{C}$ showed higher activity, thus was a better choice than $\mathrm{Ni} / \mathrm{Al}_{2} \mathrm{O}_{3}$. While in THF and cyclohexane, $\mathrm{Ni} / \mathrm{Al}_{2} \mathrm{O}_{3}$ was superior to $\mathrm{Ni} / \mathrm{C}$. The reasons why different supports influence the activity of $\mathrm{Ni}$ may be ascribed to their varying $\mathrm{Ni}$ surface areas. Stability study shows that $\mathrm{Ni} / \mathrm{C}$ is better than $\mathrm{Ni} / \mathrm{Al}_{2} \mathrm{O}_{3}$ in aqueous ammonia. This work is helpful for us to further understand the factors that could affect the amination of alcohol.

Acknowledgments: This research was supported by grants from the National Natural Science Foundation of China (No. 11204003, No. 21273260, No. 21433001, and 21303238), the Natural Science Foundation of Anhui Province (No. 1508085SMB209), the Anhui Provincial Key Science Foundation for Outstanding Young Talent (No. 2013SQRL022ZD) and Shandong Provincial Natural Science Foundation for Distinguished Young Scholar, China (No. JQ201305).

Author Contributions: Y.Q. and H.Y. conceived and designed the experiments; Q. Y. performed the experiments; Y.Q., H.Y., Q.C and X.M. analyzed the data; B.D. and A. M. contributed reagents/materials/analysis tools; Y.Q. wrote the paper.

Conflicts of Interest: The authors declare no conflict of interest.

\section{References}

1. Imm, S.; Bähn, S.; Neubert, L.; Neumann, H.; Beller, M. An efficient and general synthesis of primary amines by ruthenium catalyzed amination of secondary alcohols with ammonia. Angew. Chem. Int. Ed. 2010, 49, 8126-8129. [CrossRef] [PubMed]

2. Pingen, D.; Müller, C.; Vogt, D. Direct amination of secondary alcohols using ammonia. Angew. Chem. Int. Ed. 2010, 49, 8130-8133. [CrossRef] [PubMed] 
3. Gunanathan, C.; Milstein, D. Selective synthesis of primary amines directly from alcohols and ammonia. Angew. Chem. Int. Ed. 2008, 120, 8789-8792. [CrossRef]

4. Pingen, D.; Diebolt, O.; Vogt, D. Direct amination of bio-alcohols using ammonia. ChemCatChem 2013, 5, 2905-2912. [CrossRef]

5. Walther, G.; Deutsch, J.; Martin, A.; Baumann, F.-E.; Fridag, D.; Franke, R.; Kçckritz, A. $\alpha$, $\omega$-functionalized C19 Monomers. ChemSusChem 2011, 4, 1052-1054. [CrossRef] [PubMed]

6. Kirumakki, S.R.; Papadaki, M.; Chary, K.V.R.; Nagaraju, N. Reductive amination of cyclohexanone in the presence of cyclohexanol over zeolites H $\beta$ and HY. J. Mol. Catal. A Chem. 2010, 321, 15-21. [CrossRef]

7. Becker, J.; Niederer, J.P.M.; Keller, M.; Hölderich, W.F. Amination of cyclohexanone and cyclohexanol/cyclohexanone in the presence of ammonia and hydrogen using copper or a group VIII metal supported on a carrier as the catalyst. Appl. Catal. A Gen. 2000, 197, 229-238. [CrossRef]

8. Chary, K.V.R.; Seela, K.K.; Naresh, D.; Ramakanth, P. Characterization and reductive amination of cyclohexanol and cyclohexanone over $\mathrm{Cu} / \mathrm{ZrO}_{2}$ catalysts. Catal. Commun. 2008, 9, 75-81. [CrossRef]

9. Baumann, W.; Spannenberg, A.; Pfeffer, J.; Haas, T.; Kçckritz, A.; Martin, A.; Deutsch, J. Utilization of common ligands for the ruthenium-catalyzed amination of alcohols. Chem. Eur. J. 2013, 19, 17702-17706. [CrossRef] [PubMed]

10. Yang, Q.; Wang, Q.; Yu, Z. Substitution of alcohols by N-nucleophiles via transition metal-catalyzed dehydrogenation. Chem. Soc. Rev. 2015, 44, 2305-2329. [CrossRef] [PubMed]

11. Cui, X.; Dai, X.; Deng, Y.; Shi, F. Development of a general non-noble metal catalyst for the benign amination of alcohols with amines and ammonia. Chem. Eur. J. 2013, 19, 3665-3675. [CrossRef] [PubMed]

12. Hayes, K.S. Industrial processes for manufacturing amines. Appl. Catal. A Gen. 2001, 221, 187-195. [CrossRef]

13. Shimizu, K.-I.; Kon, K.; Onodera, W.; Yamazaki, H.; Kondo, J.N. Heterogeneous Ni catalyst for direct synthesis of primary amines from alcohols and ammonia. ACS Catal. 2013, 3, 112-117. [CrossRef]

14. Fujita, K.-I.; Enoki, Y.; Yamaguchi, R. Cp*Ir-catalyzed $N$-alkylation of amines with alcohols. A versatile and atom economical method for the synthesis of amines. Tetrahedron 2008, 64, 1943-1954. [CrossRef]

15. Fujita, K.-I.; Fujii, T.; Yamaguchi, R. Cp*Ir complex-catalyzed N-heterocyclization of primary amines with diols: A new catalytic system for environmentally benign synthesis of cyclic amines. Org. Lett. 2004, 6, 3525-3528. [CrossRef] [PubMed]

16. Du, X.-L.; He, L.; Zhao, S.; Liu, Y.-M.; Cao, Y.; He, H.-Y.; Fan, K.-N. Hydrogen-independent reductive transformation of carbohydrate biomass into $\gamma$-valerolactone and pyrrolidone derivatives with supported gold catalysts. Angew. Chem. Int. Ed. 2011, 50, 7815-7819. [CrossRef] [PubMed]

17. Chidambaram, M.; Bell, A.T. A two-step approach for the catalytic conversion of glucose to 2,5-dimethylfuran in ionic liquids. Green Chem. 2010, 12, 1253-1262. [CrossRef]

(C) 2016 by the authors; licensee MDPI, Basel, Switzerland. This article is an open access article distributed under the terms and conditions of the Creative Commons Attribution (CC-BY) license (http://creativecommons.org/licenses/by/4.0/). 